\title{
Effect of oxide additions on the properties of plasma-sprayed $\mathrm{Y}-\mathrm{Ba}-\mathrm{Cu}-\mathrm{O}$ coatings
}

\author{
K A DURGA PRASAD, K C LAHIRY, D MAHESWARA \\ REDDY, S C MOHAN, S RAJENDRA KUMAR, N \\ RAMADASS, S RAVICHANDRAN, R SOMASUNDARAM. G \\ SWAMINATHAN and $K$ VENUGOPAL \\ Corporate Research and Development, Bharat Heavy Electricals Limited. Hyderabad \\ 500593 , India
}

\begin{abstract}
Plasma-spraying is a potential technique for forming flexible tapes from the brittle high $T_{c}$ oxides. It is possible to obtain superconducting $\mathrm{YBa}_{2} \mathrm{Cu}_{3} \mathrm{O}_{x}$ coatings by a suitable heat-treatment after spraying. In an effort to improve the critical current densities of the coatings, the effect of additions of $\mathrm{Ag}_{2} \mathrm{O}, \mathrm{Bi}_{2} \mathrm{O}_{3}$ and $\mathrm{SnO}_{2}$ to the $\mathrm{YBa}_{2} \mathrm{Cu}_{3} \mathrm{O}_{x}$ powder used for spraying was studied. The maximum $J_{c}$ value of $75 \mathrm{~A} / \mathrm{cm}^{2}$ was obtained for the sample doped with $5^{\circ}, \mathrm{SnO}_{2}$.
\end{abstract}

Keywords. YBaCuO system; plasma spray; critical current density; additives

\section{Introduction}

Plasma spraying is a viable technique for production of flexible tapes of high temperature ceramic superconductors. There have been several attempts in this direction (Kirkland et al 1987; Cuomo et al 1987; Karthikeyan et al 1988; Konaka et al 1988). A common feature of these studies is the necessity of a suitable heat treatment cycle for recovery of superconducting properties in the plasma-sprayed coatings. Although superconducting coatings have been obtained, the reported values of critical current densities have been low. The effect of doping the $\mathrm{YBa}_{2} \mathrm{Cu}_{3} \mathrm{O}_{x}(1-2-3)$ powder with oxides such as $\mathrm{Ag}_{2} \mathrm{O}, \mathrm{Bi}_{2} \mathrm{O}_{3}$ and $\mathrm{SnO}_{2}$ on the critical current densities $\left(J_{c}\right)$ of the plasma-sprayed and heat-treated coatings has been studied. The essential consideration for additions of these oxides was the possibility of improved intergrain contact, thereby increasing the $J_{c}$.

\section{Experimental}

The powder used for spraying was prepared as follows: Stoichiometric quantities of $\mathrm{Y}_{2} \mathrm{O}_{3}, \mathrm{BaCO}_{3}$ and $\mathrm{CuO}$ were mixed thoroughly and calcined at $900^{\circ} \mathrm{C}$ for $24 \mathrm{~h}$ followed by cooling at $50^{\circ} \mathrm{C} / \mathrm{h}$ in air. This operation was performed thrice with intermediate grindings. The powder was prepared in batches of $500 \mathrm{~g}$. The size fraction $-170,+320$ mesh was selected for further processing. This powder was mixed separately with $5^{\circ}$, $\mathrm{Ag}_{2} \mathrm{O}, 5 \% \mathrm{Bi}_{2} \mathrm{O}_{3}$ and $5 \% \mathrm{SnO}_{2}$ in a planetary ball mill.

Stainless steel (grade 304) strips (size $5 \mathrm{~cm} \times 1 \mathrm{~cm}$ ) were used as substrates which were degreased, grit-blasted and given a bond coat of silver (thickness $100 \mu$ ) by the wirespray technique. The bond coat was essential to obtain adherent films of the superconducting oxides and to prevent their reaction with the substrate. 
The superconductor powder thus prepared was then sprayed on to the substrate using a Bay State abrasive gun at a power level of $18 \mathrm{~kW}$. The powder was fed internally and argon was used as the plasma and powder-carrier gas. The deposited coatings were $100 \mu$ thick. The samples, after spraying, were immediately transferred to a tubular furnace whose temperature was maintained at $600^{\circ} \mathrm{C}$ and allowed to cool slowly. They were subsequently heat-treated at $900^{\circ} \mathrm{C}$ for $5 \mathrm{~h}$ in $\mathrm{O}_{2}$ atmosphere followed by slowcooling at $50^{\circ} \mathrm{C} / \mathrm{h}$ with intermediate holds at $700^{\circ} \mathrm{C}, 600^{\circ} \mathrm{C}$ and $400^{\circ} \mathrm{C}$ for $1 \mathrm{~h}, 1 \mathrm{~h}$ and $3 \mathrm{~h}$ respectively. This optimum cycle follows the work of Venugopal et al (1989).

The structure of the powder and the sprayed coatings before and after heat treatment was determined by X-ray diffraction using a cobalt anode X-ray source tube. The superconducting transition temperature $\left(T_{c}\right)$ and critical current density $\left(J_{c}\right)$ were measured using the conventional dc four-probe technique. The samples were given a top coat of silver and heated to $500^{\circ} \mathrm{C}$ followed by slow-cooling in oxygen prior to electrical measurements. This was done to passivate the superconducting coatings against atmospheric attack and to improve the electrical contacts.

\section{Results and discussion}

The 1-2-3 powder used for spraying was found to be single-phase orthorhombic $\mathrm{YBa}_{2} \mathrm{Cu}_{3} \mathrm{O}_{x}$ according to the $\mathrm{X}$-ray diffraction pattern. The coating in the as-sprayed condition was poorly crystalline. The heat-treated samples showed a predominantly orthorhombic 1-2-3 structure.

All samples showed a superconducting transition temperature of about $84 \mathrm{~K}$. The critical current densities of the samples are shown in table 1 . While addition of $\mathrm{Bi}_{2} \mathrm{O}_{3}$ and $\mathrm{Ag}_{2} \mathrm{O}$ reduced the $J_{c}$ when compared to the undoped sample, the addition of $\mathrm{SnO}_{2}$ considerably improved $J_{c}$.

\section{Conclusion}

It is found possible to improve the critical current density of plasma-sprayed $\mathrm{YBaCuO}$ coatings using suitable additives. Further investigations on the effect of additive concentration on $J_{c}$ with a view to improving the same and the reasons for the reduction in $J_{c}$ with the additives of $5 \% \mathrm{Ag}_{2} \mathrm{O}$ and $\mathrm{Bi}_{2} \mathrm{O}_{3}$ are under progress.

Table 1. $J_{c}$ values of sprayed coatings heat-treated at $900^{\circ} \mathrm{C}$ for 5 hours.

\begin{tabular}{lc}
\hline Powder mixture & $J_{c}\left(\mathrm{~A} / \mathrm{cm}^{2}\right)$ \\
\hline $1-2-3$ & 55 \\
$1-2-3+5 \% \mathrm{Ag}_{2} \mathrm{O}$ & 15 \\
$1-2-3+5 \% \mathrm{Bi}_{2} \mathrm{O}_{3}$ & 32 \\
$1-2-3+5 \% \mathrm{SnO}_{2}$ & 75 \\
\hline
\end{tabular}




\section{References}

Cuomo J J, Guarnieri C R, Shivashankar S A, Roy R A, Yu D S and Rosenberg R 1987 Adv. Ceram. Mater. 2 422

Karthikeyan J, Sreekumar K P, Kurup M B, Patil D S, Anantapadmanabhan P V, Venkataramani M and Rohatgi V K 1988 J. Phys. D21 1246

Kirkland J P, Neiser R A, Herman H, Elam W T. Sampath S, Skelton E F, Gansert D and Wang H G 1987 Adv. Ceram. Mater. 2401

Konaka T. Sankawa I, Matsuuara, Higashi T and Ishihara K $1988 . J p n . ~ J$. Appl. Phys. Lett. 27 L1092

Venugopal K, Swaminathan G, Rajendra K S, Reddy D M and Mohan S C 1990 J. Mater. Sci. Lett. 91137 